\title{
COMMUNICATIVE EXERCISES AS A COMPONENT OF FOREIGN LANGUAGE PROFESSIONAL COMPETENCE OF FUTURE DOCTORS
}

\author{
Г. Я. Кітура, І. І. Ворона, Н. Я. Ковтун \\ Тернопільський національний медичний університет імені І. Я. Горбачевського МОЗ України \\ КОМУНІКАТИВНІ ВПРАВИ ЯК СКЛАДОВА ІНШОМОВНОЇ ФАХОВОЇ \\ КОМПЕТЕНТНОСТІ МАЙБУТНІХ ЛІКАРІВ
}

\begin{abstract}
The article deals with the practical usage expediency of English language communicative exercises as a component of medical students' professional competence. The essence of foreign language competence as a constituent of the professional culture of Health Care worker is ascertained. The formation of a medical student's foreign language competence is an important concept of the professional education in higher educational medical establishments and is realized by mastering the features of language competence at its phonetic, lexical and grammatical levels of study. The attention is concentrated on the necessity of educational communicative exersices' analysis as a core component of English for Specific Purposes (ESP). The problems of special subject contents within the course of ESP, selection of teaching materials, development of students' communicative component in the mastering of the English language skills are examined. The main components of the medical students' lexical competence are described; science-based classification system of exercises for the formation of communicative competence is considered; the necessity of lexical mastering for proper opinion formation is emphasized. The examples of communicative lexical exercises for the implementation of professional speech activities of medical students in professional English classes are suggested. The practical usage of the communicative exercises develops speech skills and abilities for an opportunity to evaluate, express own opinions and promote self-development and self-actualization of medical students is clarified in this article.
\end{abstract}

Key words: English for Specific Purposes (ESP); communicative exercises; foreign language professional competence; system of exercises.

Анотація. Стаття присвячена обгрунтуванню доцільності використання англомовних комунікативних вправ як складової формування фахової компетентності у студентів медичних ВНЗ. 3’ясовано суть іншомовної компетенції, що є важливим концептом професіограми майбутнього працівника охорони здоров’я. Наголошується, що формування іншомовної фахової компетентності студента-медика є невід’ємним аспектом професійно орієнтованого навчання у медичному ВНЗ і здійснюється шляхом опанування особливостей мовної компетенції на ії фонетичному, лексичному та граматичному рівнях вивчення. Увага акцентується на необхідності аналізу навчальних лексичних завдань як фундаментальної основи курсу іноземної мови за професійним спрямуванням (ESP). Розглядаються питання змістового наповнення курсу ESP, відбору навчального лексичного матеріалу, розвитку комунікативного компонента в процесі оволодіння студентом іншомовними фаховими уміннями. Охарактеризовано основні складові лексичної компетенції студентів-медиків, розглянуто науково обгрунтовану класифікацію системи вправ для формування мовленнєвої компетенції; наголошено на необхідності засвоєння лексики для правильного оформлення висловлювання. Запропоновано зразки комунікативних лексичних вправ, які необхідні для здійснення фахової мовленнєвої діяльності студентів-медиків на заняттях англійської мови за професійним спрямуванням. 3'ясовано, що використання комунікативних завдань на заняттях англійської мови за професійним спрямуванням розвиває мовленнєві навички та вміння, які надають можливість давати оцінку, висловлювати власну думку і сприяють саморозвитку та самоактуалізації студентів-медиків.

Ключові слова: англійська мова за професійним спрямуванням (ESP); комунікативні вправи; іншомовна фахова компетентність; система вправ.

(c) H. Ya. Kitura, I. I. Vorona, N. Ya. Kovtun 
Introduction. A foreign language professional communication as an activity scope promotes information exchange in the process of communication, awareness of concepts and phenomena inherent in a particular professional area, ability to participate in cultural dialogue, using skills to apply acquired professional knowledge in speech properly. Professional activity of the medical workers requires impeccable professional skills as well as professional foreign language competence, which they need for studying original literature, work with colleagues from around the world, creative and purposeful development of skills, and increasing their professional competitiveness.

Recently, a global intensification of economic, scientific and technological activities has caused development of English for Specific Purposes (ESP) in the world approaches in teaching English as a foreign language. The attention to ESP in medicine was paid mainly because of reorientation of the need for an innovative high quality training of skilled specialists. At present, higher education is intended to develop foreign language competence in students, which is an integral part of a future doctor's professional culture. Competence is an essential result of mastering a relevant competence - "a set of interconnected knowledge, skills, and abilities related to the subject of study that allows performing purposeful and effective actions using it" [4]. I. Zimniaia considers expertise as requirements and norms, and competencies - as the level of compliance of the subject to these requirements [3]. Development of foreign language professional competence of a medical student, which is an integral aspect of professionally oriented education in a medical university, is carried out by mastering language competence regarding its phonetic, lexical and grammatical levels of study.

The aim. Development of science requires professional English language skills for performing professional duties by experts in different field. The aim of the study is to substantiate the feasibility of development of English language professional speech competence of a medical student using a set of lexical professional communicative tasks in the ESP course.

Theoretical framework. The concept of speech competence is theoretically and practically substantiated in the studies of A. Bogush, I. Zimniaia, M. Pentyliuk. The optimal ways of development of foreign language professional competence of a future specialist are determined in the studios of N. Borysova, L. Morska, S. Nikolaieva, O. Tarnopolsky, N. Fedchyshyn. The complex study of the meaning and methods of ESP language competencies development is also performed by American and English scholars D. Bell, T. DudleyEvans, G. Perren, and T. Hutchinson.

Development of communicative skills is the main goal of professional English-language training of medical students for professional dialogue and international specialization in medicine. According to T. Hutchinson, ESP is interpreted as an approach to language acquisition, in which the content of learning material and teaching methods are based on reasons that urge students learning the language [11, p. 10]. S. Krashen, R. McKay emphasize that, taking into account the specialization, language learning provides students with both foreign language knowledge and professional skills, which they can successfully apply in the subjects of the main cycle or in practice [12]. The obtained information enables narrowing the language range in preparation of materials for relevant speech needs of the students.

The concept of foreign language professional speech competence of a student can be defined by using a variety of communicative tasks during foreign language classes for professional purposes that allows for communication. In this aspect, the language and speech ability of the student is an integral prerequisite for development of speech competence as a certain level of language competence of the subject. Professional foreign language competence of a medical student is developed in three aspects of language acquisition: language competence (language knowledge), speech competence (language proficiency) and communicative competence (using a language). In the language system we distinguish the levels that correspond to the language system levels: phonetic, lexical, grammatical, understanding of which contributes to development of speech activity. Phonetic competence is manifested in the normative articulation and pronunciation of sounds. Lexical competence combines lexical structures in a particular language system. Grammatical competence is developed at morphological, syntactic and wordforming sublevels, respectively.

To define the specifics of foreign language speech competence of a competitive medical worker, it is necessary to analyse the means of learning it is developed through. Analysis of learning and methodological literature of English-language specialization and training at medical universities confirm that the educational communicative tasks suggested by the authors of textbooks and manuals in ESP are aimed at solving the problem of foreign language competence of medical students; they are addressed to consolidate 
grammatical and lexical structures as well as to develop different types of oral communication. Thus, the tasks aimed at development of speech, mostly containing a creative element, are usually more complex than the tasks for speaking skills development (of introductory and training function) and involve a structured organization of students independent work. These exercises define aspects of lexical competence; its basis is phonetic and grammatical competence. The main goals of lexical tasks for professional (medical) purposes are the ability to express, prove and disprove an opinion, to tell and ask about a fact, subject, event, etc. Each of the professional English language communicative tasks has a common goal - a focus on communication and active mental activity of the student, independent use of terminological vocabulary in real life situations, and ability to formulate a professional communicative intention.

L. Fiorito emphasizes that the study of English for professional purposes should be part of a professional subject area important for the student and a significant basis for their interest in mastering the language [10]. J. Allen also argues that students' interest in learning professional English is supported by a true sense of the value of association between English lessons and the processes that take place in a physics laboratory, engineer's workshop or at surgeon's operating table [8, p. 9]. It is important that student's interest in their specialization encourages them for cooperation with colleagues and studying world's professional achievements through specialized literature that contributes to development of foreign language skills.

N. Fedchyshyn underlines different types of texts and test tasks offered for processing of language material and training of students' receptive, reproductive and productive skills and at the same time to control the level of formation of their speaking competence. Educational materials include a vocabulary-minimum, grammar help, and lists of basic language formulas to express different communicative intentions [9, p. 34].

S. Nikolaieva states that according to the communicative criterion, exercises for speech development are divided into communicative, non-communicative, conditionally communicative [5, p. 30]. Noncommunicative tasks are preparatory and aimed at consolidation of using of lexical and grammatical units on the subject necessary outside the speech situation paying great attention to the form.

Among the lexical exercises that promote development of professional speech, the exercises of conditionally communicative and communicative ones are the foremost, because they involve use of language material in pseudo-real professional communication. The conditionally communicative tasks are characterized by development of skills of primary memorizing of lexical units. The communicative exercises help the student realize the act of English speech and are aimed at development of ability to use the studied lexical material in all types of communication, to solve complex creative problems that are similar to a real professional situation of communication. The conditionally communicative exercises are developed at the level of words, word combinations, phrases, and communicative exercises use sentences and text. This provides a gradual transition from studying and assimilation of medical tokens by medical students to free forming of sentences and, subsequently, to situational use of the acquired language material when expressing their own opinions.

The conditionally communicative pre-text tasks aimed at development of professional lexical competence consolidate phonetic competence that allows activating students' ability to speak and listen. The exercises for development of foreign language speech skills are conditionally communicative, partially controlled, provide for a presence of a speech task and provide the principle of interactivity, as well as a possibility of using auditory and visual content. Key words, structural speech schemes, definitions, terms, etc. can serve as such support. Please see the examples of conditionally communicative tasks that can be used in development of English language professional competence of a medical student (Fig. 1).

The main purpose of the communication exercises is the use of existing professional lexical skills and abilities in various types of speech activity. Such exercises are designed for individual work as well as group work. Communicative tasks are post-text, as they render the professional information of the read text. They are aimed at development and motivation of professional communicative intentions, ability to creatively use lexical units in English language prepared and unprepared speech and are interesting in modern ESP. We suggest the following tasks (Fig. 2):

Communicative tasks contribute to development of students' professional speech automatism, gradual break through a psychological barrier of fear of communication by using clichés for interphrase communication: I can't agree; I guess; In my opinion; I'm quite sure, etc.

At the profound stage of professional text processing, the following tasks can be suggested to students: 
- $\quad$ Translate the following word combinations and make up your own sentences.

to begin, to emerge, to be rooted, to follow a routine of oral hygiene, to be essential for the formation of healthy

teeth, to be susceptible to decay, lack of vitamins, to irritate gums ...

$[1$, p. 100]

- $\quad$ Find substitutes for the following word combinations. Then use them in the sentences of your own.

1. one of the pair of organs of respiration, situated in the chest cavity a. heart

2. a hollow muscular cone-shaped organ, lying between the lungs b. bone

3. the hard extremely dense tissue that forms the skeleton of the body c. lungs

[6, p. 10]

- $\quad$ Give opposites of the following.

Accessory part, slightly connected, easy to separate, lowermost part, to curve upward, large area, upper lip, in front of the ears ...

[7, p. 98]

- $\quad$ Point out a wrong word or words in the following groups.

1. Liver, pancreas, oesophagus, intestine, lungs, stomach.

2. Blood vessels, lymph vessels, the tissues, gastric cancer, lymph nodes.

3. Intravenous, intramuscular, subcutaneous, internal, external.

[2, p. 146]

Fig. 1. Conditional-communicative pre-text exercises.

- $\quad$ Replace the words in bold type by a word or a word combination of words from the text.

1. The torso is the central part of the body.

2. The gullet is located in the thoracic cavity.

3. The trunk houses very important organs.

- $\quad$ Odd one out. In each set of words one is the odd one out: different from the others. Find the word that is different and say why.

1. vein artery endothelium endothelium

2. venules arterioles aorta _-

3. smooth muscle connective tissue capillary

[6, p. 249]

- $\quad$ Say whether the following statements are true or false. Comment on your answer.

1. Diabetes mellitus is a disorder in which glucose blood levels are abnormally low.

2. In both insulin-dependent and non-insulin dependent diabetes the pancreas manufactures insulin at higher than normal levels.

3. Obesity is a risk factor for the development of diabetes.

[2, p. 294-295]

Fig. 2. Post-text communicative exercises.

compose or complete a dialogue, answer questions, translate the text, create and voice a professional multimedia presentation, find Ukrainian equivalents to English idioms and discuss their meaning, etc. (Fig. 3):

Creative exercises for lexical competence improve communicative skills of future doctors, develop their ability to integrate existing speech skills in pseudo-real professional situations, increase interest in learning English, expand foreign language competence and allow activating all previously acquired knowledge. Thus, H. Widdowson emphasizes the need for students to feel involved in communicative activities, but not

- Complete the open dialogue:

- How do you do.

- How do you do.

- I have a very bad toothache, but I don't know which tooth it is.

[1, p. 121]

- Multimedia Power Point Presentation. Create four to six slides (regarding one body system) for a class Power Point presentation on the systems of the human body.

- Skeletal - bones, joints

- Muscular - muscles

$[6$, p. 73$]$

- $\quad$ Learn the following word combinations and idioms. Make up your own sentences.

healthy /strong heart - здорове, сильне серце

to gladden smb's heart - приносити радість комусь

to harden smb’s heart - озлоблювати чиєсь серце

[2, p. 74-75]

Fig. 3. Communicative exercises. 
just to study the ways of using language and speech material [13, p. 35]. An American expert in teaching methodology advises to set tasks and problem-solving tasks to students that tend to cognitive processes that are part of the learning objectives. At the profound stage of work with the text, the communicative exercises that contribute to development of monologue oral skills are of great importance. Such tasks are: reading, retelling, determining the main idea of a professional text, composing a dialogue on some topic, translating professional material from Ukrainian into English, studying English language medical poetry, discussing the subject matter, rendering learning material in various creative role games, etc.

The use of creative communicative tasks during classes of English for professional purposes develops speech skills and abilities that enable assessing, expressing their own opinions by means of professional tokens and promoting self-realization and selfactualization of medical students.

\section{List of literature}

1. Аврахова Л. Я. English for Dentists : навч. посіб. для вищ. мед. навч. закл. III-IV рівнів акредитації / Л. Я. Аврахова, Ю. Е. Лавриш. - К. : Видавничий дім Асканія, 2008. - 366 c.

2. Англійська мова для студентів-медиків : підручник / [О. С. Ісаєва, Л. Я. Аврахова, І. А. Прокоп та ін.]. - Львів, 2013. - 546 с

3. Зимняя И. А. Ключевые компетенции - новая парадигма результата современного образования [Электронный ресурс] / И. А. Зимняя // Интернет-журнал «Эйдос». - 2006. - 5 мая. - Режим доступа : http://www. eidos.ru/journal/2006/0505.htm.

4. Иванова Е. О. Компетентностный подход в соотношении со знаниево-ориентированным и культурологическим [Электронный ресурс] / Е. О. Иванова // Интернет-журнал «Эйдос». - 2007. - 30 сент. - Режим доступа : http://www.eidos.ru/joumal/2007/0930-23.htm.

5. Ніколаєва С. Ю. Практикум з методики викладання англійської мови у середніх навчальних закладах / С. Ю. Ніколаєва. - К. : Ленвіт, 2004. - С. 30-31.

6. Прокоп I. А. Англійська мова за професійним спрямуванням : Медицина : навч. посіб. / І. А. Прокоп, В. Я. Рахлецька, Г. Я. Павлишин. - Тернопіль : ТДМУ, 2010. - 576 с.

7. Цебрук I. Ф. Англійська мова для студентівстоматологів : підручник / I. Ф. Цебрук, А. А. Венгри-
Conclusions and Prospects for Research. Analysis of the feasibility of communicative tasks for development of foreign language professional competence of students during classes of English for professional purposes in medical universities confirms that proficiency of professional English is impossible without perfect mastering of lexical structures. Development of speech and mental activity is facilitated by the tasks for lexical competence: non-communicative, conditionally communicative and communicative. The suggested examples of lexical exercises for ESP classes in medical universities are not a theoretical structure, but an integral aspect of development of professional foreign language competence of medical students and are used in teaching English for professional purposes. A communicative orientation of professional English contributes to optimization of educational process, training of future doctors, and provides for international professional speech activities.

нович, Н. Р. Венгринович. - Івано-Франківськ : ДВНЗ «Івано-Франківський національний медичний університет», 2012. - 480 с.

8. Allen J. B. English in physical science (English in Focus Series) / J. B. Allen, H. G. Widdowson. - Oxford : Oxford University Press, 1974. - 186 p.

9. Fedchyshyn N. O. Distance learning of future doctors in foreign language: challenges of time / N. O. Fedchyshyn, N. I. Yelahina, O. H. Permiakova // Медична освіта. 2020. - № 2 (87). - С. 33-39. - Режим доступу : https:// doi.org/10.11603/me.2414-5998.2020.2.11144.

10. Fiorito L. Teaching English for specific purposes [Electronic resource] / L. Fiorito. - 2005. - Access mode : http://www.usingenglish.com/teachers/articles/teachingenglish-for-specific-purposes-esp.html.

11. Hutchinson T. English for Specific Purposes: A learnercentered approach / T. Hutchinson, A. Waters. - Cambridge : Cambridge University Press, 1987. - 286 p.

12. Laurence A. English for Specific Purposes: What does it mean? Why is it different? [Electronic resource] / A. Laurence. - Access mode : http://www.antlab.sci.waseda.ac.jp/ abstracts/ESParticle.html.

13. Widdowson H. G. An approach to the teaching of scientific English discourse / H. G. Widdowson // RELC Journal. - 1977. - No. 5. - P. 33-39. 


\section{References}

1. Avrakhova, L.Ya., \& Lavrysh, Yu.E. (2008). English for Dentists: Navchalnyi posibnyk dlia vyshchykh medychnykh navchalnykh zakladiv III-IV rivniv akredytatsii [Textbook for higher medical educational institutions of III-IV ${ }^{\text {th }}$ levels of accreditation]. Kyiv: Vydavnychyi dim Askaniia.

2. Isaieva, O.S., Avrakhova, L.Ya., Prokop, I.A., ... Korneiko, I.V. (2013). Anhliiska mova dlia studentivmedykiv: Pidruchnyk [English for medical students: Textbook]. Lviv [in Ukrainian].

3. Zimnyaya, I.A. (2006). Klyuchevye kompetentsii - novaya paradigma rezultata sovremennogo obrazovaniya [Key competencies are a new paradigm of the result of modern education]. El. zhurnal "Eydos" - El. Journal "Eydos". Retrieved from: http://www.eidos.ru/journal/2006/0505. htm. [in Russian].

4. Ivanova, E.O. (2007). Kompetentnostnyy podhod v sootnoshenii so znanievo-orientirovannym i kulturologicheskim [Competence approach in relation to knowledge-oriented and culturological ones]. Internet-zhurnal «Eydos» - Internet Journal “Eydos”. Retrieved from: http://www.eidos.ru/ joumal/2007/0930-23.htm [in Russian].

5. Nikolaieva, S.Yu. (2004). Praktykum z metodyky vykladannia anhliiskoi movy u serednikh navchalnykh zakladakh [Workshop on methods of teaching English in secondary schools]. Kyiv: Lenvit [in Ukrainian].

6. Prokop, I.A., Rakhletska, V.Ya., \& Pavlyshyn, H.Ya. (2010). Anhliiska mova za profesiinym spriamuvanniam:
Medytsyna: navch. posib. dlia stud. vyshch. navch. zakl. IV rivnia akredytatsii [Professional English: Medicine] Ternopil: TDMU [in Ukrainian].

7. Tsebruk, I.F., Venhrynovych, A.A., \& Venhrynovych, N.R. (2012). Anhliiska mova dlia studentivstomatolohiv: Pidruchnyk [English for dental students: Textbook]. Ivano-Frankivsk: Ivano-Frankivsk National Medical University [in Ukrainian].

8. Allen, J.B., \& Widdowson, H.G. (1974). English in physical science (English in Focus Series). Oxford: Oxford University Press.

9. Fedchyshyn, N.O., Yelahina, N.I., \& Permiakova, O.H. (2020). Distance learning of future doctors in foreign language: challenges of time. Retrieved from: https://doi. org/10.11603/me.2414-5998.2020.2.11144.

10. Fiorito, L. (2005). Teaching English for specific purposes. Retrieved from: http://www.usingenglish.com/teachers/articles/teaching-english-for-specific-purposes-esp.html [in English].

11. Hutchinson, T., \& Waters, A. (1987). English for Specific Purposes: A learner-centered approach. Cambridge: Cambridge University Press.

12. Laurence, A. English for Specific Purposes: What does it mean? Why is it different? Retrieved from : http://www. antlab.sci.waseda.ac.jp/abstracts/ESParticle.html.

13. Widdowson, H.G. (1977). An approach to the teaching of scientific English discourse. RELC Journal, 5, 33-39.

E-mail address for correspondence: voronai@tdmu.edu.ua 